DOI: $10.2478 /$ lpts-2018-0032

\title{
ACCURATE MODEL FOR TEMPERATURE DEPENDENCE OF SOLAR CELL PERFORMANCE ACCORDING TO PHONON ENERGY CORRECTION
}

\author{
Y. Tiandho ${ }^{1,2 *}$, W. Sunanda ${ }^{1,3}$, F. Afriani ${ }^{2}$, A. Indriawati ${ }^{1,2}$, T. P. Handayani ${ }^{4}$ \\ ${ }^{1}$ Research Center for Energy and Information Technology, \\ Universitas Bangka Belitung, Indonesia \\ ${ }^{2}$ Department of Physics, Universitas Bangka Belitung, Indonesia \\ ${ }^{3}$ Department of Electrical Engineering, Universitas Bangka Belitung, Indonesia \\ ${ }^{4}$ Department of Information System, \\ Universitas Muhammadiyah Gorontalo, Indonesia \\ *e-mail: yuant@ubb.ac.id
}

\begin{abstract}
In many experiments, it has been reported that the performance of solar cells decreases with increasing temperature. This effect arises due to an increase in the intrinsic carrier concentration of material that directly affects the reverse saturation currents $\left(J_{0}\right)$. As a result, the open circuit voltage which is inversely proportional to $J_{0}$ will decrease quite rapidly with increasing temperature. The intrinsic carrier concentration is determined by the bandgap energy of a material and its temperature. The Varshni relationship is a relation for the variation of the bandgap energy with temperature in semiconductors that has been used extensively in the model of a solar cell performance. But the problem is the Varshni relation just calculates the contribution of the vibrational part at the temperature, which is much greater than the Debye temperature. These works proposed a model of temperature dependence of solar cell performance that involves phonon energy correction and electron-phonon coupling interaction. This correction is applied because the electron-phonon coupling interaction is an intrinsic interaction of semiconductors. The existence of interaction cannot be avoided either experimentally or theoretically. The proposed model is compared with experimental data, which have fairly high accuracy.
\end{abstract}

Keywords: phonon, semiconductor, solar cell, temperature

\section{INTRODUCTION}

Being concerned about the limited sources and pollution effects of fossil fuels, various countries all over the world have been developing renewable energy sources [1], [2]. The use of solar cells, which are devices that can directly convert sunlight into electrical energy, provides huge potential in both economic and environmental 
benefits [3]. In addition, the solar cell systems also provide easy installation so that they can be used to supply electricity for people who do not have access to the main electrical source [4].

Reliability is one of the important factors in the selection of solar cells besides their efficiency [5]. Solar cells that cannot survive in extreme environmental conditions will have an impact on increased maintenance costs that will increase the electricity price. There are several environmental factors that affect the performance of solar cells such as dust [6], humidity [7] and temperature [8]. However, the temperature is the most important factor because in terrestrial application, solar cells are generally exposed to temperature ranging from $15^{\circ} \mathrm{C}$ to $50^{\circ} \mathrm{C}$. In addition, the use of solar cells has covered a wider field such as space and concentrator systems that have higher temperatures [9].

Many studies have reported that the performance of solar cells decreases as temperature increases. The performance of solar cells is expressed by the characteristics of short circuit current density $\left(J_{S C}\right)$, open circuit voltage $\left(V_{O C}\right)$, fill factor $(F F)$ and efficiency $(\eta)$. Some solar cell models state that the working of solar cells is equivalent to a series of combinations of current sources (which are generated by light) with a diode [10]. Therefore, the value of solar cell performance parameters is related to a diode parameter. Some diode parameters of a solar cell are reverse saturation current density $\left(J_{O}\right)$ and an ideal factor, which is related to the resistance. It has been shown that the $V_{O C}$ has decreased with temperature even though $J_{S C}$ has slightly improved. The temperature rise also causes a decrease in $F F$ and $\eta$ due to the significance of $V_{O C}$ change to temperature. Many cases have reported that the temperature is not significant in changing the resistance but $J_{O}$ is exponentially dependent on temperature [9], [10].

The temperature dependence of $J_{O}$ arises from the relation between the saturation current density and the bandgap of a material. In literature, it is stated that parameter $J_{O}$ contains the intrinsic carrier concentration variable of the semiconductor material $n_{i}$, i.e $[11,9]$.,

$$
J_{o}=q n_{i}^{2}\left(\frac{1}{N_{D}} \sqrt{\frac{D_{p}}{\tau_{p}}}+\frac{1}{N_{A}} \sqrt{\frac{D_{n}}{\tau_{n}}}\right),
$$

where $q$ is the elementary charge, $D_{P}$ and $D_{n}$ are the diffusion coefficients of holes and electrons, $N_{A}$ and $N_{D}$ are acceptor and donor constants, and $\tau_{P}$ and $\tau_{n}$ are the lifetime carriers of holes and electrons. Then $n_{\mathrm{i}}$ is expressed as a variable that depends on the band gap as [9]

$$
n_{i}^{2}=4\left(\frac{2 \pi k T \sqrt{m_{n}^{*} m_{p}^{*}}}{\hbar^{2}}\right)^{3} \exp \left(-\frac{E_{g}}{k T}\right),
$$

where $T$ is temperature, $m_{n}^{*}$ and $m_{p}^{*}$ are effective mass of electrons and holes whereas $k$ and $\hbar$ are Boltzmann constant and Planck constant. According to both equations, it is clear that the important factors in the calculation of $J_{O}$ are strongly dependent on the bandgap and its temperature. 
It has been reported that the energy of the semiconductor bandgap depends on temperature [12]-[14]. Higher temperature reduces its bandgap. Varshni proposes a formula that is often used to describe the dependence of the semiconductor bandgap on the temperature in a non-linear relation [12]

$$
E_{g}(T)=E_{g}(0)-\frac{\alpha T^{2}}{(\beta+T)}
$$

where $\operatorname{Eg}(0)$ is a bandgap energy at $T \approx 0 \mathrm{~K}$, and $\alpha$ and $\beta$ are characteristic fitting parameters that depend on material type. This relation is also often used to describe the performance of solar cell that depends on temperature [8], [9]. In Varshni's model it is stated that the variation of bandgap energy with temperature is generated by two mechanisms: (1) a shift in the relative position of the conduction band and the valence band due to the dependence of lattice dilatation to temperature, and (2) the relative positioning of the conduction band and valence due to the dependence of the electron lattice interaction. Although the Varshni relation provides a good relationship on the bandgap energy (especially in the III-V and II-VI semiconductors), it cannot be generally applicable. The Varshni relation just calculates the vibrational parts at temperature, which is much higher than the Debye temperature. As an example, chalcopyrite compound is incompatible with Varshni relation [14].

Around the 1990s, O'Dennell and Chen proposed a model of the relationship between the bandgap energy and the temperature that involved the intrinsic interaction of a semiconductor called the electron-phonon interaction [14]. Through the relations which were formulated on the vibronic-based model, O'Dennell and Chen provided better correction of the bandgap energy-temperature relationship. In addition, they also calculated the thermodynamic functions, such as Gibbs energy, enthalpy and entropy from the electron-hole pair formation in semiconductors. Therefore, to improve the calculation of solar cell performance as a function of temperature and to eliminate the effect of $\beta$ constants that may be unphysical, in this paper we propose a new model involving electron-phonon interaction. Experimental data verify the accuracy of the model.

\section{MODELLING}

When a solar cell is illuminated, only the photons having energy higher than the bandgap energy $\left(E_{g}\right)$ can excite electrons and create electron-hole pairs. O'Dennell and Chen [14] proposed the model of the bandgap-temperature relations

$$
E_{g}(T)=E_{g}(0)-S\langle\hbar \omega\rangle\left(\operatorname{coth}\left(\frac{\langle\hbar \omega\rangle}{2 k T}\right)-1\right)
$$

where $S$ is the coupling constant and $\langle\hbar \omega\rangle$ is the average phonon energy. Figure 1 shows the comparison between the Varshni relationship and the bandgap-temperature relationship based on phonon energy correction for the GaAs and Si semicon- 
ductors. In this case, Si semiconductors have higher bandgap compared to GaAs. Based on comparison with experimental data, it appears that the phonon energy correction gives better results than Varshni relationship. In this model, it is clear that the semiconductor bandgap decreases with increasing temperature.

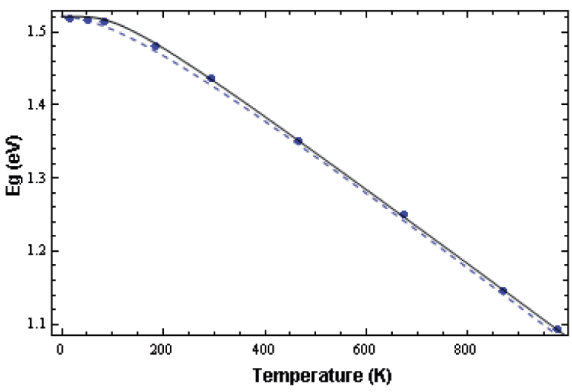

(a)

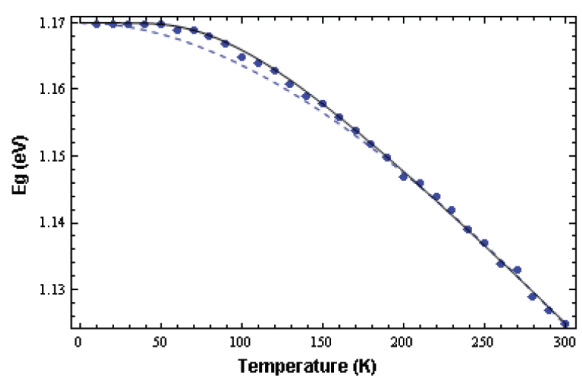

(b)

Fig. 1. Energy bandgap as a temperature function for the Varshni relation (dashed) and the phonon energy correction (line) in the experimental data of semiconductors (dots): (a) GaAs and (b) Si [14].

For a simple overview, an equivalent circuit of an ideal solar cell is the combination of a current source (the current generated by light) and a diode as shown in Fig. 2(a). The solar cell behaves similarly to diodes and its electrical characteristics are represented by the voltage-current density (current) curve (J-V curve) as shown in Fig. 2(b). The J-V curve characteristics of p-n junction solar cells under steady state illumination can be summarised in the exponential model,

$$
J=J_{L}+J_{0}\left(e^{q V / A k T}-1\right)
$$

where $J_{L}$ represents current density, $V$ is the terminal voltage (developed across the junction voltage) and $A$ is the ideal factor of the diode. This paper ignores the resistance of system because temperature changes do not change the resistance in the circuit significantly.

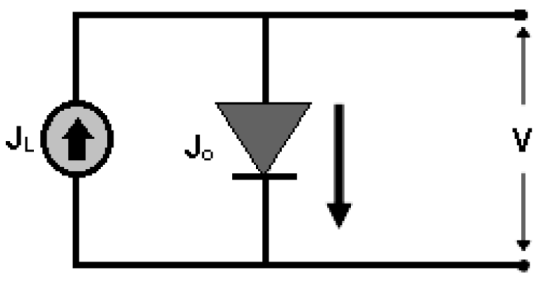

(a)

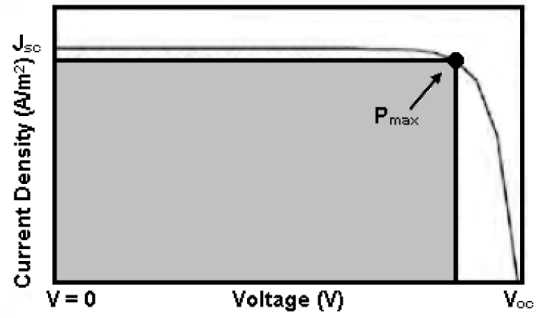

(b)

Fig. 2. (a) Equivalent circuit of an ideal solar cell and (b) J-V curve.

On the $\mathrm{J}-\mathrm{V}$ curve it is possible to determine several variables related to solar cell performance such as $J_{S C}, V_{O C}, P_{\max }, F F$, and efficiency. $J_{S C}$ is a variable that 
represents the short circuit current density that is the maximum value of the current density that occurs when the solar cell voltage is zero. $V_{O C}$ is the open circuit voltage which is the maximum voltage when the current is zero. $P_{\max }$ is the maximum power produced by a solar cell with a value determined by the maximum $\mathrm{J}-\mathrm{V}$ variables. The $F F$ or fill factor is a variable associated with the ratio of $P_{\max }$ with the multiplication of $V_{O C}$ and $J_{S C}$

$$
F F=\frac{P_{\max }}{V_{O C} J_{S C}}
$$

Therefore, the efficiency of solar cell can be defined as ratio of $P_{\max }$ to input power

$$
\eta=\frac{P_{\max }}{P_{\text {in }} \text { Area }} \text { or } \eta=\frac{V_{O C} J_{S C} F F}{P_{i n}}
$$

According to Eq. (5), it is stated that the $V_{O C}$ is given by

$$
V_{o c}=\frac{A k T}{q} \ln \left(\frac{J_{s c}}{J_{0}}\right)
$$

where $q$ is the charge of electrons. Basically, $J_{0}$ is a measure of the leakage or recombination of the minor carrier passing through the $p-n$ junction in a reverse bias condition. Through Eqs. (1) and (2), the relationship between $J_{0}$ and temperature can be expressed by the relationship

$$
J_{0}=C T^{3} \exp \left(-\frac{E_{g}}{m k T}\right)
$$

where $C$ is an empirical parameter that depends on the type of material and doping. The $m$ is an empirical parameter that depends on the quality of material cells and junctions, for high purity monocrystalline material the $m$ value is one. In [9], it is also stated that $C$ is a constant that relates to the atom density of donor and acceptor, the diffusion constant of the minority carriers in regions $\mathrm{p}$ and $\mathrm{n}$, the diffusion length of the minority carriers, the electron and hole masses, and the densities of conditions in the conduction band and valence. Nevertheless, through the expression in Eq. (9), it can be seen that the bandgap is inversely proportional to the saturation current density. Hence, substituting Eq. (9) with Eq. (4) and Eq. (8) lead produces the relation between temperature with $V_{O C}$

$$
V_{o c}=\frac{A k T}{q} \ln \left(J_{s c} / C T^{3} \exp \left(-\frac{E_{g}(0)-S\langle\hbar \omega\rangle(\operatorname{coth}(\langle\hbar \omega\rangle / 2 k T)-1)}{m k T}\right)\right) .
$$


The current density of $J_{S C}$ is a variable that depends on the spectral irradiation of sunlight and in experimental experience the value of $J_{S C}$ can be limited by reflection losses, electrical resistance losses, shadowing losses and recombination losses [9]. Basically, the formula of the $J_{S C}$ is very complex, i.e., $J_{s c}=q \int_{h v=E_{g}}^{\infty}\left(d N_{p h} / d v\right) d(h v)$ : where $N p h$ is the photon density; and $v$ is the frequency of the photon, to obtain $J_{S C}$ value and its derivative to the temperature explicitly, numerical analysis is used. Experiments regarding the determination of $J_{S C}$ values for different types of solar cell materials have been reported by Green [16] for measurements under the AM 1.5G spectrum, while Wysocki and Rappaport [17] - for measurements under the AM 0G spectrum. The results show that it is safe to say that in general the AM 0G spectrum can produce $J_{S C}$ higher than the AM $1.5 \mathrm{G}$ spectrum for different types of solar cell materials such as $\mathrm{Si}, \mathrm{GaAs}, \mathrm{CdTe}, \mathrm{Ge}, \mathrm{InP}$, and $\mathrm{CdS}$ [9].

Based on the definition described above, the temperature dependence of $V_{O C}$ can be obtained through the relationship

$$
\frac{d V_{o c}}{d T}=\frac{A k T}{q}\left(\frac{1}{J_{s c}} \frac{\partial J_{s c}}{\partial T}-\frac{1}{J_{0}} \frac{\partial J_{0}}{\partial T}\right)+\frac{V_{o c}}{T}
$$

and the relationship between the dependence of the saturation current density $J_{0}$ and the temperature can be expressed as

$$
\frac{\partial J_{0}}{\partial T}=3 C T^{2} \exp \left(-\frac{E_{g}}{m k T}\right)+C T^{3} \exp \left(-\frac{E_{g}}{m k T}\right)\left(\frac{E_{g}}{m k T^{2}}-\frac{1}{m k T} \frac{\partial E_{g}}{\partial T}\right)
$$

According to[15], the definition of fill factor in Eq. (6) is modified as follows:

$$
F F=\frac{V_{m}}{V_{o c}}\left(1-\frac{F\left(\exp \left(\frac{q V_{m}}{k T}\right)-1\right)}{G\left(\exp \left(\frac{q V_{o c}}{k T}\right)-1\right)}\right),
$$

where $F$ and $G$ are the parameters that arise from the relationship between $V_{m}$ with $J_{m}$ and $V_{O C}$ with $J_{S C}$. Therefore, with simple modification $V_{m}$ satisfies the relationship

$$
\exp \left(\frac{q V_{m}}{B k T}\right)\left(1+\frac{q V_{m}}{B k T}\right)=\frac{J_{s c}}{J_{0}}+1
$$

where $B$ is an empirical parameter. Explicitly, $V_{m}$ can be expressed as follows:

$$
V_{m}=\frac{B k T\left(\operatorname{productLog}\left(\frac{\exp \left(J_{o}+J_{s c}\right)}{J_{o}}\right)-1\right)}{q},
$$


where productLog is a function related to a logarithmic solution, e.g., ProductLog (z) provides a solution for $w$ in $z=w \mathrm{e}^{\mathrm{w}}$. Thus, the temperature dependence on the fill factor satisfies

$$
\begin{aligned}
\frac{d F F}{d T}= & \frac{\left(1-\frac{\exp \left(q V_{m} / k T\right)-1}{\exp \left(q V_{o c} / k T\right)-1}\right) V_{m}^{\prime}}{V_{o}}-\frac{\left(1-\frac{\exp \left(q V_{m} / k T\right)-1}{\exp \left(q V_{o c} / k T\right)-1}\right) V_{m} V_{o c}{ }^{\prime}}{V_{o c}{ }^{2}} \\
& +\frac{V_{m} \exp \left(q V_{0} / k T\right)\left(-1+\exp \left(q V_{m} / k T\right)\right)\left(q V_{o c}{ }^{\prime} / k T-q V_{o c} / k T^{2}\right)}{V_{o c}\left(\exp \left(q V_{o c} / k T\right)-1\right)^{2}} \\
& -\frac{V_{m} \exp \left(q V_{m} / k T\right)\left(q V_{m}{ }^{\prime} / k T-q V_{m} / k T^{2}\right)}{V_{o c} \exp \left(q V_{o c} / k T\right)-1}
\end{aligned}
$$

where $V_{m}{ }^{\prime}=\partial V_{m} / \partial T$ and $V_{o c}{ }^{\prime}=\partial V_{o c} / \partial T$.

Through these relationships, the temperature dependence of the efficiency can be expressed by formula:

$$
\frac{1}{\eta} \frac{\partial \eta}{\partial T}=\frac{1}{V_{o c}} \frac{\partial V_{o c}}{\partial T}+\frac{1}{J_{s c}} \frac{\partial J_{s c}}{\partial T}+\frac{1}{F F} \frac{\partial F F}{\partial T} .
$$

\section{CONFIRMATION WITH EXPERIMENTAL DATA}

In this section, the model proposed is compared with experiment data from [18] and [15]. In the beginning, the model and the experimental results were compared with regard to the relation between temperature to $V_{O C}$ value that has been done by Tobnaghi et al. (2013) using monocrystalline silicon solar cells. Since there is no analytic expression of temperature dependence of $J_{S C}$ in Fig. 3 we obtain the expression through linear fitting method: $J_{S C}=33.7491+0.00083 \mathrm{~T}$ and $\partial J_{s c} / \partial T=0.00083$.

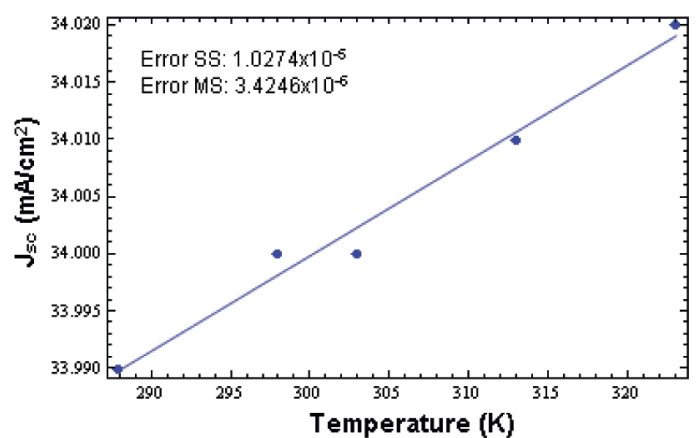

Fig. 3. Linear fitting of the relationship between $J_{S C}$ and the temperature on the solar cell in [18]. 
The relation between $E_{\mathrm{g}}(0)$, average phonon energy, and electron-phonon coupling parameters of silicon and GaAs are shown in Table 1. The changes in performance parameters: $J_{S C}, V_{O C}, V_{m}, F F$, and efficiency are reported in Fig. 4. Using Eq. (10) along with the $J_{S C}$ expression and the bandgap energy parameter data from silicon, the comparison between the model and the experimental results is shown in Fig. 4(a). It is clear that the proposed model, which has the $V_{O C}$ properties inversely proportional to the temperature, is acceptable because the model can provide a small variance and almost similar to all experimental data. This result is also obtained by parameters fitting solar cells in [18], which are $C=2476.23 \mathrm{~mA} \mathrm{~cm}^{-2} \mathrm{~K}^{3}, A=0.2145$, and $m=0.3545$. Thus, it can be stated that the quality of solar cell was low according to its $m$ parameter.

Table 1

Energy Gap Parameters for Si and GaAs [14]

\begin{tabular}{lccc}
\hline & $E_{g}(0)(\mathrm{eV})$ & $S$ & $\langle\hbar \omega\rangle(\mathrm{meV})$ \\
\hline $\mathrm{Si}$ & 1.170 & 1.49 & 25.5 \\
$\mathrm{GaAs}$ & 1.521 & 3.00 & 26.7 \\
\hline
\end{tabular}

The comparison of $V_{m}$ values as in Eq. (15) with the experimental results is shown in Fig. 4(b). The expression of $J_{0}$ is determined by Eq. (9). Through the fitting data obtained value $B=0.1766$ for solar cells in [18]. Furthermore, in Fig. 4(c) it appears that the expression of the $F F$ formulation in Eq. (13) is sufficient in accordance with the experimental results. The constant values of $F$ and $G$ are 1.924 and 2.304, respectively. It is clear that in the temperature range from $288 \mathrm{~K}$ to $323 \mathrm{~K}$ the value of $F F$ is inversely proportional to the temperature. Thus, based on these performance parameters, it is clear that the efficiency of the solar cell will also be inversely proportional to the temperature as shown in Fig. 4(d). The efficiency of a solar cell will decrease with increasing temperature. Thus, based on the suitability of all models of solar cell performance parameters on the experimental results it can be stated that the model we proposed has high accuracy to describe the dependence of solar cell performance on temperature changes.

Apart from the above four parameters, we also verify the temperature dependence of $V O C$ on the experimental results of $\mathrm{Si}$ and GaAs solar cells in [15]. Based on the experimental data in [15], Table 1 and the $V_{O C}$ expression as a function of temperature in Eq. (11) we obtain $\left(1 / V_{o c}\right)\left(\partial V_{o c} / \partial T\right)=-0.24 \%$ for GaAs solar cells with $V_{O C}=0.96 \mathrm{~V}$ at $300 \mathrm{~K}$. As for solar cell Si with $V_{O C}=0.67 \mathrm{~V}$ at $300 \mathrm{~K}$ we obtain $\left(1 / V_{o c}\right)\left(\partial V_{o c} / \partial T\right)=-0.30 \%$. Our calculations are very close to the experimental results where the results of $\left(1 / V_{o c}\right)\left(\partial V_{o c} / \partial T\right)$ in GaAs solar cell is $-0.25 \%$ while for $\mathrm{Si}$ solar cell is $-0.30 \%$. In addition, our calculations are more accurate than Fan's (1986) calculations. The difference in results arises from the application of phononic energy correction and the phonon-electron coupling in our calculations. 


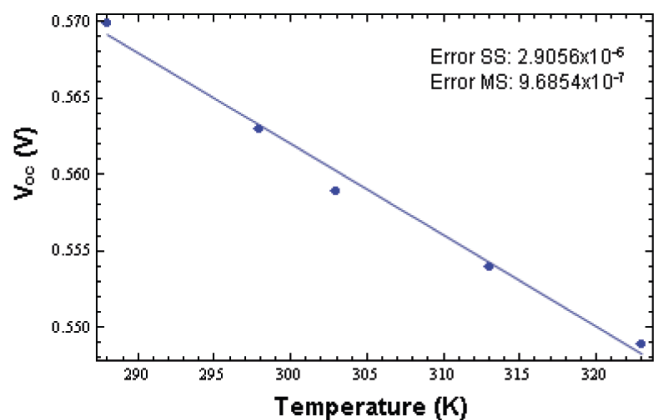

(a)

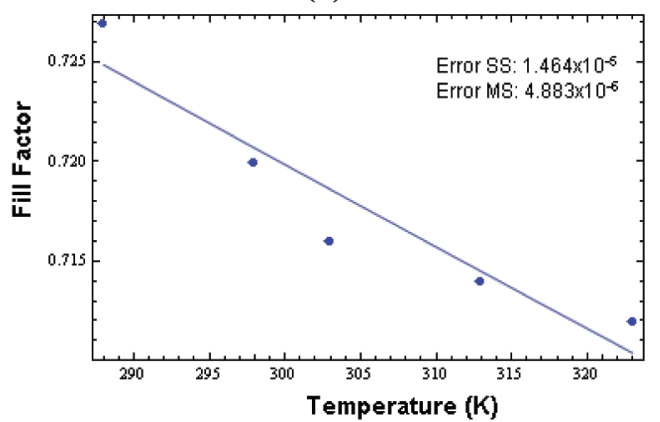

(c)

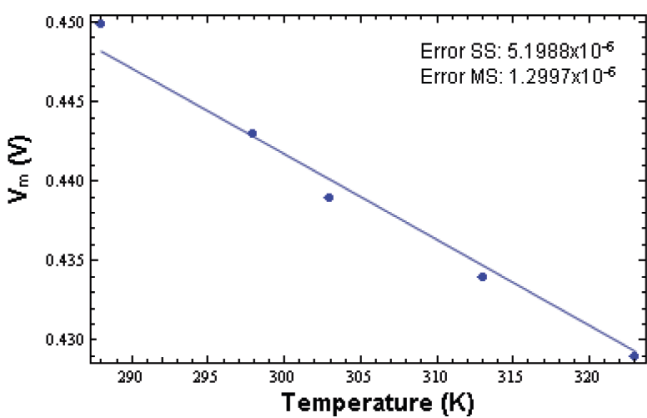

(b)

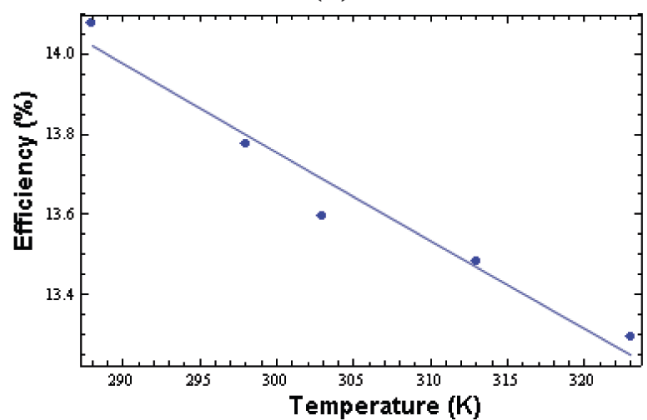

(d)

Fig. 4. The values of solar cell performance parameters: (a) $V_{O C}$, (b) $V_{m}$, (c) $F F$, and (d) efficiency as a function of temperature in [18].

\section{CONCLUSIONS}

Through expression of bandgap relationship with temperature involving, electron-phonon coupling interaction can be shown that the higher temperature will decrease solar cell performance parameters such as: $V_{O C}, V_{m}, F F$, and the efficiency. The models with the electron-phonon interaction correction are quite accurate. The experimental values of $V_{O C}, V_{m}, F F$, efficiency and temperature dependence of $V_{O C}$ are almost similar to the proposed model.

\section{ACKNOWLEDGEMENTS}

We gratefully acknowledge the funding from USAID through the SHERA programme - Centre for Development of Sustainable Region (CDSR).

\section{REFERENCES}

1. Hitha, P., Sosale, S.S., Sushmitha, S., \& Rekha, K.R. (2017). Performance analysis of various-4-wheelers with IC engines for hybridization. International Journal of Advance Research, Ideas, and Innovations in Technology 3(3), 1322-1327.

2. Chu, S., Cui, Y., \& Liu, N. (2017). The path towards sustainable energy. Nature Materials 16, 16-22. 
3. Ferreira, A., Kunh, S.S., Fagnani, K.C., De Souza, T.A., Tonezer, C., Santos, G.R.D., \& Coimbra-Araujo, C.H. (2018). Economic overview of the use and production of photovoltaic solar energy in Brazil. Renewable and Sustainable Energy Reviews 81, 181-191.

4. Khemariya, M., Mittal, A., Baredar, P., \& Singh, A. (2017). Cost and size optimization of solat photovoltaic and fuel cell based integrated energy system for un-electrified village. Journal of Energy Storage, 14, 62-70.

5. Huang, X., Fu, H., Chen, H., Lu, Z., Baranowski, I., Montes, J., Yang, T.H., Gunning, B.P., Koleske, D., \& Zhao, Y. (2017). Reliability analysis of InGaN/GaN multi-quantumwell solar cells under thermal stress. Applied Physics Letters, 111, 2333511.

6. Saidan, M., Albaali, A., Alasis, E., \& Kaldellis, J. (2016). Experimental study on the effect of dust deposition on solar photovoltaic panels in desert environtment. Renewable Energy, 92, 499-505.

7. Sun, Y., Wu, Y., Fang, X., Xu, L., Ma, Z., Lu, Y., Zhang, W.H., Yu, Q., Yuan, N., \& Ding, J. (2017). Long-term stability of organic-inorganic hybrid perovskite solar cells with high efficiency under high humidity conditions. J. Mater. Chem., A 5, 1374-1379.

8. Perl, E.E., Simon, J., Geisz, J.F., Lee, M.J., Friedman, D.J., \& Steiner, M.A. (2017). Measurements and modelling of III-V solar cells at high temperatures up to $400^{\circ} \mathrm{C} .2017$ IEEE 44th Photovoltaic Specialist Conference (PVSC), 1-14.

9. Singh, P., \& Ravindra, N. (2012). Temperature dependence of solar cell performance-an analysis. Solar Energy Materials \& Solar Cells, 101, 36-45.

10. Tamrakar, V., Gupta, S., \& Sawle, Y. (2015). Single-diode PV cell modeling and study of characteristics of single and two-diode equivalent circuit. Electrical and Electronics Engineering: An International Journal, 4(3), 13-24.

11. Schubert, E. (2006). LED basics: Electrical properties. Light-Emitting Diodes. Cambridge: Cambridge University Press.

12. Varshi, Y. (1967). Temperature dependence of the energy gap in semiconductors. Physics (Utrecht), 34, 149-154.

13. Cuce, E., Cuce, P.M., Karakas, I.H., \& Bali, T. (2017). An accurate model for photovoltaic (PV) modules to determine electrical characteristics and thermodynamic performance parameters. Energy Conversion and Management, 146, 205-216

14. O’Donnell, K., \& Chen, X. (1991). Temperature dependence of semiconductor band gaps. Appl. Phys. Lett. 58(15), 2924-2926.

15. Fan, F. (1986). Theoretical temperature dependence of solar cell parameters. Solar Cells, 17, 309-315.

16. Green, M., Emery, K., Hishikawa, Y., \& Warta, W. (2011). Solar cell efficiency tables (version 37). Progress in Photovoltaics: Research and Applications, 19, 84-92.

17. Wysocki, J., \& Rappaport, P. (1960). Effect of temperature on photovoltaic solar energy conversion. Journal of Applied Physics, 31, 571-578.

18. Tobnaghi, D., Madatov, R., \& Naderi, D. (2013). The effect of temperature on electrical parameters of solar cells. International Journal of Advanced Research in Electrical, Electronics and Instrumentation Engineering, 2(12), 6404-6407. 


\title{
PRECİZS MODELIS SAULES ELEMENTU EFEKTIVITĀTES ATKARĪBAI NO TEMPERATŪRAS PĒC FONONA ENERGIJIAS KOREKCIJAS
}

\author{
J. Tiandho, V. Sunanda, F. Afriani, A. Indriavati, T. P. Handajani
}

Kopsavilkums

Daudzos eksperimentos tiek ziņots, ka saules elementu efektivitāte samazinās, pieaugot temperatūrai. Šis efekts rodas materiāla iekšějo nesēju koncentrācijas pieauguma dēl, kas tieši ietekmē atgriezenisko piesātinājuma strāvu $\left(J_{0}\right)$. Rezultātā, tukšgaitas spriegums, kas ir apgriezti proporcionāls $J_{0}$, samazinās diezgan strauji, pieaugot temperatūrai. Iekšējā nesēja koncentrācija tiek noteikta, izmantojot materiāla brīvo elektronu enerǵiju un tās temperatūru. Varšni attiecība ir saistība starp brīvo elektronu enerǵijas izmainām un pusvadītāju temperatūru, kas plaši izmantota saules elementu efektivitātes modelī. Tomēr pastāv problēma, jo Varšni attiecība nosaka tikai vibrācijas dalıas devumu, un tas attiecas tikai uz temperatūru, kas ir daudz lielāka par Debaja temperatūru. Pētījumos tiek piedāvāts saules elementu efektivitātes temperatūras atkarības modelis, kas ietver fonona enerǵijas korekciju un elektronu-fononu mijiedarbību. Šì korekcija tiek piemērota, jo elektronufononu sakabes mijiedarbība ir pusvadītāju raksturīgā mijiedarbība. Mijiedarbības esamību nevar izslēgt nedz eksperimentāli, nedz teorētiski. Piedāvātais modelis tiek salīdzināts ar eksperimentāliem datiem, kuriem ir diezgan augsta precizitāte.

29.06.2018. 